\title{
D. H. Lawrence's Aesthetics in Selected Poems of Birds, Beasts and Flowers (*)
}

\author{
Supervised by: \\ Professor Mohamed Enani \\ Faculty of Arts, Cairo University
}

\section{Riham Atef Morshed \\ Masters of English Comparative Literature, American University in Cairo}

\begin{abstract}
:
D. H. Lawrence shows an overwhelming interest in the relationship between man, nature and time. As this relationship requires a comprehending interaction with entities that are distinctive, some of Lawrence's poems discuss notions of being and time, which reflects his affinities with Martin Heidegger, who extensively discusses enriching ideas on humanity and existence. One of the things that distinguishes Heidegger from other philosophers is his coinage of his own philosophic language and terminology, and his abandonment of traditional methods of thinking, so he created the term Dasein, which refers to the consciousness of being-in-the-world, and being-in-the-world in consciousness at the same time. All Heidegger's terms represent his attempts to explain 'presence' wherein da refers to the place (being here or being there); hence, it also entails the concept of time. Lawrence, too, was preoccupied by the existence of man within the universe and his relationship with it. In Birds, Beasts and Flowers, Lawrence manipulates the sense of movement to demonstrate this relationship which he sees as both harmonious and essential, and this reflects the influence of the philosophy of Vitalism on his thought. The aim of this paper is to show how the poems' style is not only aesthetic but also philosophical as they depict Lawrence's concern with the question of existence and the interpretation of life. The poems manifest Lawrence's deep understanding of time as he creates for both man and other living things their own temporal spaces in which they move separately. The study will
\end{abstract}

(*) D. H. Lawrence's Aesthetics in Selected Poems of Birds, Beasts and Flowers , Vol. 10, Issue No.1, Jan. 2021, pp.77-107. 


\section{H. Lawrence's Aesthetics in Selected Poems of Birds,}

Beasts and Flowers

attempt to show how he shatters the passive contemplation to become part of the 'being' he is studying.

\section{Keywords}

Existentialism, Martin Heidegger, Time, Being, Tortoise, Lawrence

الملخص

يظهر د. لورنس اهتمامًا كبيرًا بالعلاقة بين الإنسان والطبيعة والوقت نظرًا لأن هذه العلاقة تتطلب تفاعلً شاملاً مع كيانات مميزة ، تتاقش بعض قصائد لورنس مفاهيم الوجود والزمن ، وهو ما يعكس ارتباطاته مع مارتن هايدجر ، الذي يناقش بدقة الأفكار المثرية عن الإنسانية والوجود. ويتميز هايدجر عن الفلاسفة الآخرين بصياغته للغته ومصطلحاته الفلسفية وتركه لطرق التفكير التقليديه، لذلك ابتكر مصطلح دازن والذي يعني الوعي بالوجود أو الوعي بالعالم وتهدف إلي محاولة فهم الوجود، فيثير المقطع دا إلي الوجود هنا وهناك وبالنالي فإنه ينطوي علي مفهوم الزمن و يثارك لورانس هايدجر في إنشغاله بقضية الوجود وخاصة وجود الإنسان في عالمه وعلاقته بهذا العالم.

في قصائد الطيور والوحوش والأزهار ، يتلاعب لورانس بإحساس الحركة لإظهار هذه العلاقة التي يراها منسجمة وضرورية وتهدف هذه الورقة البحثية إلي مناقنشة أسلوب القصائد لتوضيح أنه ليس فقط جمالياً بل فلسفيًا لأنه يصور اهتمام لورنس بمسألة الوجود وتأثير المذهب الحيوي علي فكره. تعبر القصائد عن فهم لورنس العميق للوقت وخلقه لكل من الإنسان والكائنات الحية الأخري مساحاته الزمنية الخاصة به والتي يتحرك فيها كل على حدة وتحاول الدراسة أن توضح كيف استطاع لورانس تغيير تأمل الطبيعة من تأمل سلبي إلي إندماج في الكون حتي يصبح الفرد جزء من هذا الكيان.

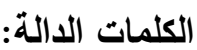
الوجودية، مارتن هايدجر ، الوقت، الوجود، السلاحف، لورانس 


\section{Introduction:}

Essentially regarded as a novelist and often praised for, or attacked on account of the autobiographical traits in his writings, D. H Lawrence has rarely been regarded as a major English poet. However, recent studies of his works have done much to rehabilitate his poetry. Going through his voluminous poetic output, one is struck by the variety of the technical qualities and the development of one or two leitmotifs in his poems. A preliminary study of his poetic imagery suggests that he was influenced by the existentialism of the 1920s, and its repercussions over the entire interwar period.

This paper examines Lawrence's style in his book Birds, Beasts and Flowers to show how he creates a stunning sense of movement and flux through depicting the harmony between man, nature and time. The paper also examines how Heidegger's notions of being and time are manifest in the poems' questioning of humanity and existence as the poet employs a poetic style that contributes to his understanding of 'time' - an understanding that enables him to overcome the anxiety of his own temporality. Birds, Beasts and Flowers is divided into nine parts: Fruits, Trees, Flowers, The Evangelistic Beasts, Creatures, Reptiles, Birds, Animals and Ghosts. In these poems, Lawrence identifies himself with nonhuman objects in nature and instead of contemplating them, he identifies himself with them and goes into their being to show what they are in themselves. In the Tortoise poems, both the poet and the tortoise move in their temporal space. The slow movement of the tortoise, contrasted with the blistering pace of Lawrence's rhythm, establishes an equilibrium that is accompanied with a harmonious combination of intellectual, emotional and physical experiences of time.

Martin Heidegger, who is best known for his contributions to existentialism, shows interest in the question of being; what does it mean to be? Heidegger believed that human being has to be existent in the middle of a world where he becomes deeply involved with the surrounding life. This notion is what Heidegger calls being-in-the-world. Similarly, Lawrence 
states that he experiences "deep satisfaction" when "getting into the perfect circuit of the earth's terrestrial magnetism."(1). In Birds, Beasts and Flowers, Lawrence experiences Heidegger's Dasein or "being-in-theworld".

\section{Body:}

Lawrence formulated his law of space and called it "the spirit of space" in November, 1918. It states that, "Every great locality expresses itself perfectly in its flowers, its own birds, beasts and lastly its own men." (2) In "The Two Principles" Lawrence tried to explain how the spirit of a place can express itself in men:

There certainly does exist a subtle and complex sympathy, correspondence between the plasm of the human body, which is identical with the primary psyche, and the material elements outside. The primary human psyche is a complex plasm, which quivers, sense-consciousness in contact with the circumambient cosmos. ${ }^{(3)}$

The poems of Birds, Beasts and Flowers are a result of Lawrence's travels during the years 1920-23. Lawrence states that, "they were begun in Tuscany, in the autumn of 1920 and finished in New Mexico in 1923 in my thirty-eighth." (4) The journey played an important role in shaping the poems of Birds, Beasts and Flowers; Keith Sagar shows the impact of the tour on Lawrence's spirituality and recovery of his "pristine self, the 'instant whole man' whose newly clarified vision found its natural utterance in Birds, Beasts, and Flowers."(5) The volume also marks a change in Lawrence's interests. In his introduction to Collected Poems, Vivian De Sola Pinto points out that in Birds, Beasts and Flowers, Lawrence "found a new theme which freed him from the trammels of autobiography. It was a subject matter that he was particularly well-qualified to treat: the immediate apprehension of the flux of life, especially of sexual life in non-human organisms... he is carrying forward the work of the great Romantics ... in the exploration of the divine otherness of non-human life."(6) Lawrence believes that man's psychological balance is drastically influenced by the 
overwhelming strain he experiences because of civilization. The impact of the theory of existentialism is obvious in his attempts to communicate with natural forces through an unconventional study of birds, beasts and flowers where he is capable of going into the being of natural objects as they form an evidence of a primordial intuitive existence which human beings once shared, but from which he was isolated. In 'The Two Principles', he discusses 'the creative mystery':

Surely the universe has arisen from some universal living self-conscious plasm, plasm which has no origin and no end, but is life eternal and identical, bringing forth the infinite creatures of being and existence, living creatures embodying inanimate substance. ${ }^{(7)}$

Lawrence's relation to nature is not confined - like the Romantics - to the different modes of being, for it transcends this. It is a relation, as Graham Hough points out, where Lawrence shatters the conventional passive contemplation to become part of the 'being' of the subject he is studying:

it is not passive appreciation; it has not much to do with beauty as such; it does use natural objects as stimulants to generalized and habitual emotions. Instead it makes an energetic and intuitive attempt to penetrate into the being of natural objects, to show what they really are in themselves, not how they can sustain our moral nature. ${ }^{(8)}$

In these poems, Lawrence intensifies his search for a vital life in the surrounding nature; his vitalist philosophy is embodied in his profound belief that all living things, even plants, have a "blood-being" and man is only part of the living cosmos. In short, his poetry reflects a vivid poetic sense of a quivering responsive life running through everything around him.

\section{Flowers:}

\section{Almond Blossom}

This poem starts the section Flowers in the collection, and it depicts the splendour of life in a simple flower. The impact of vitalism on Lawrence is 
reflected in this poem since it shows Lawrence's overwhelming interest in the annual rejuvenation of the tree in blossom, of the resurrection of the plant as he describes the renewal of life. The poem is considered a, "hymn to the miracle of renewed life." (9)

Even iron can put forth,

Even iron.

This is the iron age,

But let us take heart

Seeing iron break and bud,

Seeing rusty iron puff with clouds of blossom

Lawrence glorifies the trees' valour and virtue as they provide themselves with a new life through overcoming "December's bare iron hooks" of the almond trees that "know the deadliest poison", and the experience of flowering itself becomes symbolic of the mysterious life-motion as the process is described in detail:

And the Gethsemane blood at the iron pores unfolds, unfolds.

Pearls itself into tenderness of bud

And in a great and sacred forthcoming steps forth,

steps out in one stride

A naked tree of blossom, like a bridegroom bathing in dew,

Divested of cover,

Frail-naked, utterly uncovered

To the green night-baying of the dog-star, Etna's

Snow-edged wind

And January's loud-seeming sun

The poem is infused with images that the poet utilizes not as illustration or decoration, but as a means of thinking, for he, "thinks in images, recreating thought into feeling”, to use T. S. Eliot's phrase... there is "wit" here, too, as well as magnificence. The image of the "dog-star baying epithalamion" is a conceit at once witty and imaginative." (10) The poem contains powerful emotions that accord with the notion of vitalism as the poet celebrates the unconquerable life-force through establishing the 
experience as one of death that reoccurs every winter and which is defeated by the will of the tree. In other words, he reinforces the idea of living creatures' struggle for their existence in the ever-changing seasons.

Lawrence moves on to show how trees strive in their battle for their existence; however, trees are powerful enough to be capable of storming up frozen earth, the iron exile with "supreme annunciation" to the world emerging with the "unquenchable heart of blossom". Their survival is an outcome of their will which Lawrence describes as, "an overshadowing will ... something that frightens you". (11)

From out the iron, and from out the steel,

Flying not down from heaven, but storming up,

Strange storming up from the dense under-earth

Along the iron, to the living steel

In rose-hot tips, and flakes of rose-pale

Setting supreme annunciation to the world.

A believer in the essential, close relationship between man and his universe, Lawrence believed that both man and trees share the same desire to exist, "For man, the vast marvel is to be alive. For man, as for flowers and beasts and birds, the supreme triumph is to be most vividly, most perfectly alive." ${ }^{(12)}$ Lawrence then shows how trees parallel the human race in their suffering "down the long age"

Trees suffer, like races, down the long ages.

They wander and are exiled, they live in exile through long ages

Like drawn blades never sheathed, hacked and gone black,

The alien lands: and yet

The heart of blossom,

The unquenchable heart of blossom!

The rebirth of the almond tree is praised by Lawrence as he highlights the grandiosity of the annual resurrection of life; this is achieved through the use of diction that is charged with glamour such as "pride" "honey - 
triumph" as well as "the most exquisite splendour."

Sweating his drops of blood through the long-nighted Gethsemane

Into blossom, into pride, into honey-triumph, into most exquisite splendour.

$\mathrm{Oh}$, give me the tree of life in blossom

And the Cross sprouting its superb and fearless flowers!

Keith Sagar sums up the whole idea of resurrection described in the poem: "The annual miracle of sprouting of the tree of life is, for Lawrence, "supreme", the true resurrection" which does not degrade and destroy the body in order to release an immortal soul." "(13) Sagar denies the idea that it's a matter of preferring body to spirit; to him, it is a proof of 'that substile knot' of flesh and spirit which makes all living things." (14)

Knots of pink, fish-silvery

In heaven, in blue, blue heaven,

Soundless, bliss-full, wide-rayed, honey-bodied,

Red at the core,

Red at the core,

Knotted in heaven upon the fine light.

Lawrence depicts the physical nature of the plant throughout, but he adds new dimensions to the poem by ending it using Christian imagery, mixed with pagan mystery referred to by Persephone. He often resorts to myth as he appreciates the 'mental thinking of the pagan thinker or poet as which, "starts with an image, sets the image in motion, allows it to achieve a certain course or circuit of its own and then takes up another image." (15) the process as a, "resurrection" that, "can only follow a crucifixion." $\mathrm{He}$ explains that, "all living things which participate in the mystery are 'open' and 'given', 'six' times wide open', which is one more opening than the wounds of the crucified Christ, open, finally, to the bride who comes from 'the dense-earth', Persephone, as well as the 'fine light of heaven'." (16) The poem is a manifestation of Lawrence's quest in the true existence of his surroundings. It scrutinizes the physical reality of the trees and ends with a 
promise of resurrection.

Vitalism is manifest in the poem in the sense of the movement evoked in the trees; a movement that is created through rhythm. Written in free verse, the poem is an outcome of, "ecstasy of praise and adoration controlled by rational imagination." (17) The whole poem is a metaphor for the blooming of the human as well as the natural world.

\section{Trees}

In his preface to the "Trees" section, Lawrence quotes Empedokles: "Trees were the first living creatures to grow up out of the earth, before the sun was spread out and before day and night were distinguished." (18) imbibing in proportional measures both fire and water, male and female. The book of Trees, thereby, becomes an investigation of the uniformity of primeval life. Lawrence holds the idea that trees are reservoir of LifeMotion and holds special interest for trees.

\section{Cypresses}

Cypress is a display of the primal life flow; Lawrence employs a tone that is described by Marjorie Perloff as a voice that, "is conversational, hectoring, nervous, energetic, funny, sardonic."(19) which reflects Lawrence's overwhelming enthusiasm observing the cypresses. From the very beginning, the poet questions the flame-tall existence of the trees as he observes them with awe and appreciation. Despite the fact that all questions go unanswered, and their messages are undecipherable, Lawrence never loses interest in the plant, for he appreciates the ambiguous mystery of the various forms of life, and the cypress is a representation of one. Keith Sagar claims that these unanswered questions, are not an indication that Lawrence couldn't communicate with the cypresses, but rather, "In recognizing the cypresses as symbols and opening himself to them, he is taking something of their otherness into his blood-knowledge." (20)

Tuscan Cypress

What is it?

Folded in like a dark thought 
For which the language is lost,

Tuscan cypresses,

Is there a great secret?

Are our words no good?

The undeliverable secret,

Dead with a dead race and a dead speech, and yet

Darkly monumental in you,

Etruscan cypresses.

Ah, how I admire your fidelity,

Dark Cypresses!

In his investigation of the trees' existence Lawrence aims at calling back the dark secret of an alien consciousness. He employs the cypresses as a symbol of the sturdy, immortal quality of Etruscan life. Their existence entails "the aroma of lost human life" which reflects Lawrence's comprehension of the primordial, rapid motion of life in the leisurely ecstasy of the trees. The poem is written in free verse that comprises a hidden rhythmical structure that ensures the portrayal of the flowing flame of the trees. Pagan mystery envelops the trees, creating an existence of their own wherein they have a raison d'etre that parallels Lawrence's fascination with the manifestations of life as a sign of his philosophical views of Being.

Marjorie Peroff highlights Lawrence's realization that each plant has its own existence:

Lawrence's outrage at the bad faith of human beings gives way to a distancing of self, or more precisely, a theatrical role-playing in which the poet alternately adopts the perspective of the plant or animal that happens to be the object of his contemplation and alternately plays the dark comedian, drawing mock lessons from his careful, almost scientific observations of plant or animal behaviour. To compare cypress to Etruscan males, for example, is strictly speaking absurd, yet the "I" of cypress convinces us that the analogy makes good sense. But no sooner are we so 
convinced that the poet abruptly deflates his repeated insistence on 'the natural lingering to the voice according to the feeling ... the hidden emotional pattern that makes poetry. ${ }^{(21)}$

\section{Birds}

\section{Hummingbirds}

Keith Sagar shows how Lawrence was influenced by Crevecoeur's opinion of hummingbirds:

We have read various descriptions of birds. W. Hudson has a good one. But this one gives a curiously sharp hard bit of realization, something surely intrinsic, a jewel - sharpness and refraction inherent in the little soul of the creature [...] He sees their dark, primitive, weapon-like souls. He sees how they start and flash their wings darkly, in the spontaneous wonder of the retraction into isolation, or in a kind of vindictive self-arrogance. ${ }^{(22)}$

Lawrence interprets Crevecoeur's description in terms of creation in "The Two Principles":

Dual all the time is the creative activity: first comes forth the living apparition of new being, the perfect and indescribable singleness: and this embodied the single beauty of a new substance [...] The gems of being were created simultaneously with the gems of matter, the latter inherent in the former. ${ }^{(23)}$

\section{Humming-Birds}

I can imagine, in some otherworld

Primeval-dumb, far back

In that most awful stillness, that only gasped and hummed,

Humming-birds raced down the avenues.

Before anything had a soul,

While life was a heave of Matter, half inanimate,

This little bit chipped off in brilliance 
And went whizzing through the slow, vast succulent stems.

I believe there were no flowers, then,

In the world where the humming-bird flashed ahead of creation.

I believe he pierced the slow vegetable veins with his long beak.

Probably he was big

As mosses and little lizards, they say were once big.

Probably he was a jabbing, terrifying monster.

We look at him through the wrong end of the long telescope of Time, Luckily for us.

Lawrence's notion of vitalism is manifest in this poem. Lawrence uses vital words such as "whizzing", "chipped", jabbing”, "raced", "flashed", and "pierced" to reflect the force of the hummingbird in its origin, and this is achieved through travelling in geological time (far back). This energetic movement is juxtaposed with the "awful stillness" of the plant life. The contrast is made comprehensive through depicting it in motion as well as sound, which enhances emotional intensity and charge. Human Beings are shown to be limited compared to time, which is capitalized and given a long line of verse, whereas "luckily for us" is said in a short one.

Keith Sagar writes,

Each poem here revises itself as it goes along, yielding layer after layer of deeper meaning, yet never finished; for the meaning of any encounter with the natural world is inexhaustible. Lawrence is interested in making discoveries, not artefacts. What he hopes to discover cannot be fixed like a fly in amber. Each poem is exploratory. It does not seek to be gem-like, self-contained, finished, outside time. It exists in the dimension of time and process, and that is its life. ${ }^{(24)}$

\section{The Tortoise Poems:}

The Tortoise sequence, which contains six poems, investigates another aspect of non-human existential mystery by showing the evolution of a tortoise from birth to consummation until the fulfilment of its integrity through sex. The poems are an embodiment of Lawrence's poetic style with 
its symbolism (the tortoise's search for integrity symbolizes man's search for his wholeness through sex), the use of myths (penetrating the tiny creature's being requires mystic mode), and finally the choice of free verse (Lawrence chooses free verse to be able to capture human feelings clearly). Lawrence includes a series of images, and although each image exists in its own time and space, each maintains its relationship with the surrounding universe. Lawrence as a vitalist believed that life is not static, and consequently, he can never accept the idea that life consists in a complexity of physical and chemical activities of the same order as those found in science. Therefore, Lawrence shows how the tortoises' fluctuating movements and their forceful efforts support them in their struggle for existence. Lawrence manages to create a relationship between himself and the tortoise through a style that Sagar describes as one that is an "almost occult penetration into the being of other creatures." (25)

W. H. Auden agrees with Sagar that "Lawrence's starting point in these poems is a personal encounter between himself and some animal or flower but, unlike the romantics, he never confuses the feelings they arouse in him with what he sees and hears and knows about them." (26)

Lawrence establishes a potent relationship with the tortoises as he endows them with miraculous human dimensions; on his part, he unrestrainedly gives himself up to their space and indulges in their natural world in a way that enables him to appreciate their aesthetic beauty; meanwhile, he maintains his own sense of being. This stance is similar to Heidegger's who thinks "of every human being as born into a fundamental, 'transcendental' horizon of disclosure - as it were, the horizon of all one's horizon - and it is this he calls 'world."(27) Consequently, Lawrence succeeds in creating a unique moment of exposure of the transcendental value of existence - or in Heideggerian terminology, the 'infinitude' required to reach a wholeness of being. In "The Two Principles", Lawrence explains how a man can reach a 'state of infinitude':

By spiritual being we mean that state of being where the self excels into the universe, and knows all things by passing into 
all things. It is that blissful consciousness which glows upon the flowers and trees and sky, so I am sky and flowers, I, who am myself. It is that movement towards a state of infinitude wherein I experience my living oneness with all things. ${ }^{(28)}$

\section{Baby Tortoise:}

Lawrence encountered a baby tortoise one day at San Gervasio. Lawrence's attention was drawn to the tortoise which was, 'a tiny, fragile, half-animate bean', and he starts to question the nature of its existence as he addresses it:

You know what it is to be born alone,

Baby tortoise!

A believer in the theory of vitalism, Lawrence gives special attention to the movement of the tortoise which is a peculiar one. The first seven lines are, "rhythmically inert, too short to generate any rhythmic impetus, 'Not yet awake', 'Not quite alive." (29)

Lawrence then fills the tortoise with life and vitality so that it resembles nature's powerful creatures:

To open your tiny beak-mouth, that looks as if it would

Never open,

Like some iron door;

To lift the upper hawk-beak from the lower base

And reach your skinny little neck

And take your first bite at some dim bit of herbage,

Alone, small insect.

Tiny bright-eye.

Slow one.

Lawrence then strengthens the poem with a breathtaking sense of movement and flux:

You draw your head forward, slowly, from your little wimple 
And set forward, slow-dragging, on your four-pinned toes,

Rowing slowly forward.

Whither away, small bird?

Rather like a baby working its limbs,

Except that you make slow, ageless progress

And a baby makes none.

The repetition of the word 'slowly' reflects the immediacy of the tortoise's action. Lawrence employs verbs of motion like 'to open', 'to lift' 'to reach' to intensify the animal's movement. The poet moves on to draw a comparison between the tortoise and a baby, a comparison which he manipulates to create a relationship between time and motion. Despite the animal's slow movement, which Lawrence emphasizes through repeating the word 'slowly' in consecutive lines, it is faster than the baby's; hence, it moves quickly in its time-space. "The poem moves forward, step by step, tentative, through a series of apostrophes which begin as pure description, then range further and further in exploratory metaphor. They also recapitulate evolution, moving from bean to insect, to bird, to baby." ${ }^{(30)}$ In his attempt to understand the existence of the tortoise, Lawrence observes the creature so closely that it seems that the tortoise is the only creature in the universe, "The poet sheds all his habitual ways of seeing and responding to the creature, gives it his whole attention, as though it had just been created, and its nature had to be apprehended afresh, or as though it were the first creature in the universe, and all the laws of creation had to be inferred from it." (31)

Again the question of being is approached as a contrast is drawn between the garden and the tortoise with regards to size. The garden is vast and overgrown, and so, in proportion to the baby tortoise, it turns into an immense universe where chaos and inertia predominate, and the tortoise is required to maintain his being. The tortoise doesn't surrender to the chaos around him but rather challenges his surroundings with the "brilliance of your so tiny eyes"; the thing that fills the poet with a sense of awe and admiration for the mysterious creature's nature, and he starts posing some 
rhetorical questions which not only reinforce the sense of movement but also reflect the tortoise's power in his struggle for survival:

Are you able to wonder

Or is it just your indomitable will and pride of the first life

Looking round

And slowly pitching itself against the inertia

Which had seemed invincible?

The poem echoes Lawrence's beliefs concerning 'being', "life must have been uniform, a great unmoved, utterly homogenous infinity, a great notbeing." (32) The tortoise succeeds in his battle for his existence by asserting his selfhood.

the baby tortoise both represents and re-enacts the fragile stirring of the first life, taking the first steps out of the non-life, the dark night, then moving forward with dogged persistence, on and on in arrogant affirmation of selfhood. He represents that crucial breakthrough in evolution when the first creatures began to move freely over the earth about their own business, the first incarnation of active, free-ranging life on earth, the prototype of all higher forms. The apostrophes progressively identify the baby tortoise with the human challengers, pioneers, as he rows forward. The perfect image of rowing leads with perfect aptness to the first comparison with an individual human being, 'little Ulysses'. Another momentous breakthrough came when men stopped hugging the coast in their ships and sailed for the horizon. ${ }^{(33)}$

The poet ends the poem by taking us back to the real world; we move from 'the slow passion of pitching through immemorial ages' from remote past and gigantic scale of the physical world that supposedly surrounds the tortoise to the virtual world of the tortoise's journey.

Over the garden earth 
Small bird,

Over the edge of all things

We then witness the tortoise as he sets off on his journey of selfdiscovery, of finding his own being:

Traveler,

With your tall tucked a little on one side

Like a gentleman in a long-skirted coat.

All life carried on your shoulder,

Invincible fore-runner.

The poem is about the persistent desire to find oneself and his efforts to achieve this:

Lawrence sees both breakthroughs as manifestations of the same urge, the urge, the compulsion, to assert the self against the unknown ... knowing that life in him is more vigorous, he takes it upon his shoulder to fight the primeval god of chaos; hence, "the biochemical origins of life and the highest pitch of evolution, the human adventure, are both contained or adumbrated in this 'invincible fore-runner'. (34)

\section{Tortoise Shell:}

Lawrence starts the poem by creating two different worlds: the physical and the spiritual through evoking Christ's pain in his physical tormenting journey and his challenging path to reach the spiritual realm:

The Cross, the Cross

Goes deeper in than we know,

Deeper into life;

Right into the marrow

And through the bone.

Lawrence heightens the sense of pain by repeating the word 'deeper'; it's pain that ends in death suggested by the word 'bone'. However, Christ is 
resurrected to have another life. Lawrence demonstrates his approach of 'transcendence' which is depicted through the notion of life and death.

In "The Two Principles", Lawrence shows his interest in mathematics and its relation to understanding life:

all creation depends upon the fourfold activity. And on this root of four is all law and understanding established. Following the perception of these supreme truth, the Pythagoreans made their philosophy, asserting that all is number, and seeking to search out the mystery of the roots of three, four, five, seven, stable throughout all the universe, in a chain of truths of mathematics are only the skeleton fabric of the living universe [...]. And the Cross, the epitome of all this fourfold division, still stirs us to the depths with unaccountable emotions, emotions which go much deeper than personality and the Christ drama. ${ }^{(35)}$

In Tortoise Shell, Lawrence utilizes the figure of the tortoise shell to illustrate his beliefs on mathematics and to attempt to create a union between life and mathematics. He examines the mathematical perfection of design and seeks to understand the mystery of creation by establishing a lively existence around the tortoise at the onset of the poem: life is 'lifeclouded' and 'life-rosy'. Seen in the context of such an environment, the tortoise manages to be part of Heidegger's being-in-the world through its shell which plays a fundamental role in maintaining his place in the world as it is covered by scales which 'are locked in an arch like a bridge' - the use of the image of a 'bridge' suggests that two different worlds are being connected: the world of the poet and that of the tortoise, or the metaphysical and the physical. The poet shares the tortoise's anxiety firstly, through showing sympathy towards it and eventually through identifying with it - a notion which accords with Heidegger's idea of 'empathy' that he defines as a phenomenon which is supposedly designated to "provide the first ontological bridge from one's own subject, initially given by itself, to the other subject, which is initially quite inaccessible." ${ }^{(36)}$ In other words, it is 
likely that two different beings can exist together, where they dwell and develop through a lifetime, interconnected despite belonging to different time spaces. Heidegger's words find affinities with Lawrence's who confirmed the idea that, "There must be the rapid momentaneous association of things which meet and pass on the forever incalculable journey of creation: everything left in its rapid, fluid relationship with the rest of things."(37)

Four, and a keystone;

Four, and a keystone;

Four, and a keystone;

Then twenty-four, and a tiny little keystone.

In the above stanza, Lawrence exploits numbers to create a sense of the existence of the tortoise amidst its surrounding nature, creating a relativistic, four - dimensional space time view. As the poet holds the tortoise for inspection, the creature's physical motion 'kicking beetle' helps him to establish a relative and living relationship to the four dimensional universe. In short, Lawrence creates, "a $3 D$ image of the shell through his words, with the fourth dimension being the forward movement of the animal as it moves in its time-space and along its horizontal life or time line." (38) It needed Pythagoras to see life playing with counters on the living back Of the baby tortoise;

Life establishing the first eternal mathematical tablet, Not in stone, like the Judean Lord, or bronze, but in life-clouded, life-rosy tortoise shell

Not in stone, like the Judean Lord, or bronze, but in life-clouded, life-rosy tortoise shell

Keith Sagar broadens the poem's perspective by interpreting it in the light of the Christ drama, "The inward form of the baby tortoise, the 'plan within, is ... cruciform, a 'cross-wise cloven psyche' which is the last thing we expected to find in so dignified and self-sufficient a creature."(39) Sagar believes that, 'the image of the tortoise on his back, 'a sprottling insect', 
together with the insistence on five, strongly evokes on the crucifixion." (40)

\section{Tortoise Family Connections}

The notion of vitalism is manifest in this poem as the rhythm of motion accelerates in the first line showing the steadiness of the tortoise movement 'on he goes'; this sense of motion continues throughout the poem, 'to row', 'to travel', 'to move' until the tortoise reaches its full being 'to be'. Lawrence adds the sense of eternity and continuity of the movement through using the gerund 'moving', 'wandering'.

In his quest of man's existence, Lawrence offers the idea of man's evolution which is suggested by the words 'bud of the universe' and 'brisk egg' at the beginning of the poem. He writes in Fantasia of the Unconscious:

The first great division in the egg remains always the same, the unchanging great division in the psychic and the physical structure; the unchanging great division in knowledge and function. It is a division into polarized duality, psychical and physical, of the human being. It is the great vertical division of the egg-cell, and of the nature of man. ${ }^{(41)}$

The tortoise experiences being alone, totally independent. Lawrence acknowledges the importance of this state of being which he calls 'sensual being'; earlier he defined 'the spiritual being', and here he introduces the sensual one, "that state in which the self is the magnificent center wherein all life pivots, and lapses ... it is a magnificent central positivity, wherein the being self sleeps upon the strength of its own reality ... the self is incontestable and unsurpassable." ${ }^{(42)}$ It is therefore clear that Lawrence confirms the essential need to preserve one's identity even when one is immersed in the circumambient universe. This is Lawrence's perspective of consciousness, and he demonstrates it from the very beginning of the poems: "The first consciousness, as we saw in 'Baby Tortoise', is that 'I am I'. There remains through life the absolute need to define the self in terms of distinction from the rest of the universe". ${ }^{(43)}$ Lawrence's words in Fantasia of the Unconscious summarizes his idea: 


\section{Riham Atef Morshed}

When, in the daytime, our life is polarized upwards, towards the upward sun-wakened eyes and the mind which sees in vison, then the powerful dynamic centers of the lower body act in subservience, in their negative polarity. And then we flow upwards, we go forth seeking the universe, in vision, speech, and thought - we go forth to see all things, to know all things by acquaintance and by knowledge. One flood of dynamic flow are we, upwards polarized, in our tallness and our wide-eyed spirit seeking to bring all the universe into the range of our conscious individuality. And eager always to make new words, out of this old world, to bud new green tips on the tree of life. ${ }^{(44)}$

Lawrence's stance reveals affinities with Heidegger's notion of how Dasein is a pure expression of being, "Dasein always understands itself in terms of its existence, in terms of its possibility to be itself or not to be itself". ${ }^{(45)}$ The tortoise's arrogance makes him oblivious of his earthy mother:

It is no use my saying to him in an emotional voice:

'This is your Mother, she laid you when you were an egg,'

He does not even trouble to answer: 'Woman, what have I to do with thee?

As Lawrence contemplates the tortoise's movement, he asks, 'Does he look for a companion?' and the answer is 'no'. The tortoise moves with arrogance which does not last for long. At one point, it becomes, "essential for the tortoise to reunite with the surrounding universe to be able to discern other beings from pebbles, bits of earth and old tins." (46) Here, Lawrence sheds light on his belief in the duality of life; he claims that we as all aspects of life - possess two distinguished selves that are essential for our beings:

For I am carried away from my sunny day-self into this other tremendous self, where knowledge will not save me, but where I must obey as the sea obeys the tides. [...] This, then, 
is the duality of my day and my night being: a duality so bitter to an adolescent. For the adolescent thinks with shame and terror of his night. He would wish to have no night-self. [...] Without the night-consummation we are trees without roots. ${ }^{(47)}$

In the light of this notion of duality, opposite to the first consciousness that confirms the 'I', the second consciousness is the "absolute need to be part of the living unity. Isolation is not his birthright [...] It is the doom of every cell to split and split again, of every creature to submit to the duality of life - self and not-self, male and female, body and spirit, birth and death." (48)

Despite the tortoise's sense of loss (he is born from an egg, unaware of his parents), the tortoise maintains its independence and enjoys its fullness of being.

Moving, and being himself

Slow, and unquestioned

Wandering in the slow triumph of his own

existence,

Ringing the soundless bell of his presence in

chaos,

And biting the frail grass arrogantly,

Decidedly arrogantly.

Although the tortoise is surrounded by chaos, its existence provides it with the sense of triumph; this is attributed to the freedom the tortoise experiences; a kind of freedom which, according to Heidegger, acts as "revelation which not only founds the very possibility of something like a "free will," but also the disclosure of beings." He states that "in Dasein's "being-ahead-of-itself" [...] beings are "freed up" to the kind of beings which they potentially are [...] and at the same time Dasein is thrown into its potentiality for becoming an authentic self. ${ }^{(49)}$

Lawrence in this poem manages to break through the life - space of the male tortoise by poking him with a stick and this is part of his, "attempt to 


\section{Riham Atef Morshed}

emphasize with the creature, to get inside it and share its perception of the world and himself." (50) The poet observes the male tortoise as he experiences an overwhelming sense of chaos while seeking the female tortoise in an attempt to fulfill his sexual desire and reproduction which guarantees their continuation; in other way, he struggles again for existence through maintaining their lineage.

\section{Lui et Elle}

In this poem, the tortoise is finally 'crucified into sex'. Lawrence shows the relationship between the male and the female, and it is clear that it lacks equilibrium; the female is depicted as a 'large and matronly and rather dirty reptile mistress', whereas the male is depicted as a 'dignified stalker'. Lawrence sympathizes with the male tortoise because he is 'doomed to keep chasing the tortoise', driven by his overwhelming yearning for sex which gives a promise of a new being that is essential for the continuity of their existence along horizontal line. As he contemplates them, Lawrence is keen on keeping the sense of movement as he describes the male tortoise's will to fulfill his physical urge, "with a grim, reptile determination' belonging to 'serpent's long obstinacy':

the spear is through the side of his isolation.

His adolescence saw him crucified into sex,

Doomed, in the long crucifixion of desire, to seek his consummation beyond himself.

Divided into passionate duality,

He, so finished and immune, now broken into desirous

fragmentariness,

Doomed to make an intolerable fool of himself

In his effort toward completion again.

The female tortoise displays a powerful will in her relationship with the male. Although she needs this act of fulfillment, she denies her needs and instead moves away, and on his part he is helpless:

What can he do? 
$\mathrm{He}$ is dumb, he is visionless,

Conceptionless.

His black, sad - lidded eye sees but beholds not

As her earthen mound moves on,

But he catches the folds of vulnerable, leathery skin,

Nail-studded, that shake beneath her shell,

And drags at these with his beak,

Drags and drags and bites,

While she pulls herself free, and rows her dull mound along.

Sagar hints at the symbolic meaning of the poem, "it is clear that we are no

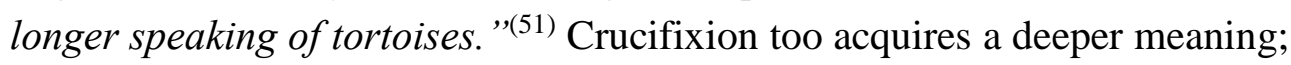
it points to the disorder that accompanies the process of creation in its struggle for survival and continuation of species during a fixed time. The physical pain experienced by the male tortoise suggested by the spear and caused by the female tortoise will to power and his desire for sex leads to his spiritual fulfillment. "Following this chaotic experience is a union of pleasure and pain, of the physical and metaphysical, leading to a temporary resurrection and to an awareness of the spiritual and the oneness of being which Lawrence refers to. " (52)

\section{Tortoise Gallantry}

Lawrence offers a totally different image of the female tortoise; he portrays her as distinctive on the physical level as well as the behavioral one. Unlike the female who had 'ugly ankle' in the previous poem, the female in the Tortoise Gallantry possesses 'vulnerable folds of skin'. Also, her attitude towards sex alters, so we see her as she 'sprawls along/in her ungainly pace'. Since Lawrence's aim is to question the nature of existence, this may suggest the "development that takes place within cyclic existence along horizontal time. The implication that beings do not have to be mere copies and repetitions of generations ... the progression of time does not have to be tediously repetitive."(53) The male tortoise pressing desire becomes poignant; Lawrence intensifies his desire by calling him 'partial 
being' :

Grim, gruesome gallantry, to which he is doomed,

Dragged out of an eternity of silent isolation

And doomed to partiality, partial being,

Ache, and want of being,

Want,

Self-exposure, hard humiliation, need to add himself on to her.

The male tortoise is distracted by the urge of his desire. He is involuntarily attracted toward the female by means of an inexplicable force. Lawrence explains natural desire very clearly showing how it arises from 'within'.

Suddenly distracted into this mazy

Sidetrack,

This awkward, harrowing pursuit,

This grim necessity from within.

The tortoise's insistence on pursuing his aim (fulfilling his desire) accords with Heidegger's notion of 'primordial freedom of Dasein'. Craig M. Nicholas calls this freedom is " a 'delivering over' to one's fateful destiny."(54) Accordingly, the experience of attaining the spiritual satisfaction is a recurrent experience, but every time it occurs, it has its own feeling of contentment and bliss. However, it is a part of whole, so after a while, the urgency starts all over again.

It is in the Tortoise Shout that the fulfillment long craved for is vigorously reached. The male tortoise cries in ecstasy as he cleaves 'behind the hovel-wall of that dense female':

A scream.

A yell,

A shout,

A paean

A death-agony

A birth-cry, 


\section{A submission}

Lawrence offers a panoramic view on the journey of man and the process of life; he traces man's endeavors to find his whole being. This is clear in the fact that the tortoise is compared to Adam throughout the poems. According to Lawrence, all male creatures need to add themselves on to Eve to attain their being and identity. Hence, when Lawrence poses the question of "Why were we crucified in sex?", the answer is that the rapturous delight of the agonizing experience of the sex act resembles the dignity and greatness of Christ's crucifixion, and it's through crucifixion that resurrection occurs. The cross itself is the path to transcendence, and the whole experience elevates both the tortoise and man to a different time and space:

This last,

Strange, faint coition yell

Of the male tortoise at extremity,

Tiny from under the very edge of the farthest far-off

Horizon of life.

Sex, which breaks us into voice, sets us calling across the deeps, calling, calling for the complement,

Singing, and calling, and singing again, being answered, having found.

Torn, to become whole again, after long seeking for what is lost,

The same cry from the tortoise as from Christ, the Osiris-cry of abandonment,

That which is whole, torn asunder,

That which is in part, finding its whole again throughout the universe.

In the Tortoise poems, Lawrence unites the poetic and the religious and the outcome is a philosophical perspective of life and existence; through applying his beliefs on vitalism, he depicts his own view of existence. He succeeds in achieving this through showing different living things struggling 
in life, and through manipulating the sense of movement and flux throughout the poems. It might be useful to include Sagar's opinion here, "The religious way of knowledge means that we accept our senseimpressions, our perceptions, in the full sense of the word, complete, and we tend instinctively to link them up with other impressions, working towards a whole... this is the way of poetic and religious consciousness, the instinctive act of synthesis." (55)

\section{Conclusion}

Lawrence's main contribution lies in his success to form his own poetic style which maintains its aesthetic beauty while discussing existential phenomena. His ingenuity is also reflected in his choice of one of the slowest and tiniest creatures, the tortoise, to study the mode of existence. His close observation of the non-human life is a unique experience which can be considered a point of revelation - a revelation which accords with Heidegger's idea which states that human beings are capable of discovering the meaning of other beings through interaction.

Lawrence sets himself free from the conventional poetic style to create a kind of poetry that encompasses scientific as well as philosophical ideas that show affinities with one of the greatest philosophers, Martin Heidegger. Lawrence resorts to free verse because he felt that the conventional rhythm impedes his poetic expression. To him, free verse was a 'vehicle' he uses to, "enable him to articulate not so much discoveries as revelations, meanings inherent in the world and in human experience being transmitted through him whenever he could be spontaneous and open and attuned enough." (56) Lawrence advocates breaking away from the traditional form; that's why he, "declines to impose a form on his insights; he relies on the structure of the experience itself to provide the structure of the work." (57) 


\section{H. Lawrence's Aesthetics in Selected Poems of Birds,}

Beasts and Flowers

\section{Notes :}

(1) D. H. Lawrence, Fantasia of the Unconscious and Psychoanalysis and the Unconscious. (Harmondsworth: Penguin Books, 1971), 121.

(2) Ezra Greenspan, Lindeth Vasey, John Worthen, eds., Studies in Classic American Literature,(UK: Cambridge University Press, 2003),178

(3) Ibid, 260

(4) Vivian De Sola Pinto, and Warren Roberts, eds., The Complete Poems of D. H. Lawrence, (Harmondsworth: Penguin Books, 1993), 28 - 29.

(5) Keith Sagar, D. H. Lawrence: Life into Art. (The University of Georgia Press, 1985), 208.

(6) De Sola Pinto, 11

(7) D. H. Lawrence: Life into Art, 208.

(8) Graham Hough, The Dark Sun: A Study of D. H. Lawrence. (New York: The Macmillan Company Capricorn Books, 1956), 201.

(9) Vivian De Sola Pinto and F. Warren Roberts, 14.

(10) Ibid, 15.

(11) Lawrence, 43

(12) Mara Kalnins, ed., Apocalypse and the Writings on Revelation. (UK: Cambridge University Press, 2002), 149

(13) Keith Sagar, D. H. Lawrence: Poet. (Humanities-Ebooks LLP, 2007), 77

(14) Ibid.

(15) Kalnins, 96

(16) D. H. Lawrence: Poet

(17) Vivian De Sola Pinto and F. Warren Roberts, 14.

(18) Edward D. McDonald, ed., Phoenix: The Posthumous Papers of D. H. Lawrence. (Great Britain: The Windmill Press Ltd. Kingswood Surrey, 1961), 65.

(19) Marjorie Perloff, Poetic License: Essays on Modernist and Postmodernist Lyric. (The United States of America: Northwestern University, 1990), 102.

(20) D. H. Lawrence: Poet, 68.

(21) Perloff, 103

(22) D. H. Lawrence: Poet, 60.

(23) Ezra Greenspan, Lindeth Vasey, John Worthen, eds. 263.

(24) D. H. Lawrence: Poet, 68.

(25) Ibid, 121

(26) A. Banerjee, ed., D. H. Lawrence: Demon Liberated. (The Macmillan Press Ltd, 1990), 239.

(27) Julian Young, Heidegger's Philosophy of Art, (Cambridge University Press, 2001), 23.

(28) Ezra Greenspan, Lindeth Vasey, John Worthen, eds., 268.

(29) D. H. Lawrence: Poet, 68.

(30) Ibid, 69 
(31) Ibid.

(32) Bruce Steele, ed., Study of Thomas Hardy, (Cambridge University Press, 1985), 42.

(33) D. H. Lawrence: Poet, 69.

(34) D. H. Lawrence: Poet, 70.

(35) Ezra Greenspan, Lindeth Vasey, John Worthen, eds., 266.

(36) Martin Heidegger, On Being and Time. Trans. Joan Stambough., (Chicago: Chicago Up, 2002), 33

(37) Banerjee, ed., 49

(38) "Harmony with Time".

(39) D. H. Lawrence: Poet, 71.

(40) Ibid.

(41)D. H. Lawrence, 37.

(42) Esra Greenspan, Lindeth Vasy, John Worthen, eds., 268.

(43) D. H. Lawrence: Poet, 72

(44) D. H. Lawrence, 179.

(45) Heidegger, 11

(46) D. H. Lawrence: Poet, 73

(47) D. H. Lawrence, $184-185$

(48) D. H. Lawrence; Poet, 72- 73

(49) 'Harmony with Time'.

(50) Ibid, 214.

(51) Ibid, 71

(52) Harmony with Time

(53) Ibid

(54)Craig M. Nicholas "Primordial Freedom: The Authentic Truth of Dasein in Heidegger's 'Being and Time'.” Thinking Fundamentals, IWM, Junior Visiting Fellow Conferences. Vol. 9.No. 2. 2000, 13

(55) D. H. Lawrence; Poet, 11

(56) Ibid, 26.

(57) Hough, 192. 


\section{Bibliography}

Banerjee, A. D. H. Lawrence: Demon Liberated. Hong Kong: The Macmillan Press Ltd. 1990.

De Sola Pinto and Warren Roberts, eds, The Complete Poems of D. H. Lawrence. Harmondsworth: Penguin Books, 1971.

Greenspan, Ezra, Lindeth Vasey and John Worthen, eds, Studies in Classic American Literature, United Kingdom: Cambridge University Press, 2003.

Heidegger, Martin. Time and Being. Trans. Joan Satmbaugh. Chicago: Chicago UP, 2002.

Hough, Graham. The Dark Sun: A Study of D. H. Lawrence. New York: The Macmillan Company, 1959.

Kalnanis, Mara, ed. Apocalypse and the Writings on Revelation. UK: Cambridge University Press, 2002.

Lawrence, D. H., Fantasia of the Unconscious and Psychoanalysis and the Unconscious. Harmondsworth: Penguin Books, 1971.

McDonald, Edward D., ed.. Phoenix: The Posthumous Papers of D. H. Lawrence. Harmondsworth Penguin Books, 1978.

Nichols, Craig M. "Primordial Freedom: The Authentic Truth of Dasein in Heidegger's 'Being and Time'." Thinking Fundamentals, IWM Junior Visiting Fellows Conferences. Vol. 9. N. 2. 2000.

Perloff, Marjorie. Poetic License: Essays on Modernist and Postmodernist Lyric. The United States of America: Northwestern University, 1990.

Sagar, Keith, D. H. Lawrence: Life into Art. The University of Georgia Press, 1985 : Poet. Humanities-Ebooks LLP, 2007.

Steele, Bruce. ed., Study of Thomas Hardy. UK: Cambridge University Press, 1985. 
Young, Julian. Heidegger's philosophy of Art. Cambridge: Cambridge University Press, 2001.

\section{Online Sources:}

El Samad, Soha. " "Harmony with Time": Lawrence's Aesthetic in the Tortoise Poems" ", Études Lawrenciennes [En ligne], 48 |2017, mis en ligne le 20 décembre 2017, consulté le 22 décembre 2018. 